\title{
Aïssa Khelladi (dir.), «Algérie Littérature/Action»
}

\section{Claudia Mansueto}

\section{(2) OpenEdition}

\section{Journals}

\section{Édition électronique}

URL : http://journals.openedition.org/studifrancesi/3897

DOI : 10.4000/studifrancesi.3897

ISSN : 2427-5856

\section{Éditeur}

Rosenberg \& Sellier

\section{Édition imprimée}

Date de publication : 1 décembre 2012

Pagination : 620

ISSN : 0039-2944

\section{Référence électronique}

Claudia Mansueto, « Aïssa Khelladi (dir.), «Algérie Littérature/Action» », Studi Francesi [En ligne], 168 (LVI | III) | 2012, mis en ligne le 30 novembre 2015, consulté le 06 mars 2021. URL : http:// journals.openedition.org/studifrancesi/3897 ; DOI : https://doi.org/10.4000/studifrancesi.3897

Ce document a été généré automatiquement le 6 mars 2021.

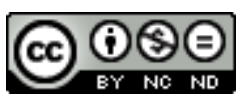

Studi Francesi è distribuita con Licenza Creative Commons Attribuzione - Non commerciale - Non opere derivate 4.0 Internazionale. 


\title{
Aïssa Khelladi (dir.), «Algérie Littérature/Action»
}

\author{
Claudia Mansueto
}




\section{RÉFÉRENCE}

AÏsSA KHELLADI (dir.), «Algérie Littérature/Action», n. 147-148, 2011, pp. 61.

1 Ce numéro de la revue comprend quatre sections thématiques distinctes: «Peinture» (pp. 5-15) qui célèbre l'éclectisme artistique d'Arezki Metref; «Poésie» (pp. 16-17) qui propose le poème «À Jean Sénac» de Azeddine Lateb; la section littéraire qui comprend les deux entretiens de Rachid MoKHTARI (pp. 19-33) et de Nadia AGSous (pp.34-44) aux intellectuels Nabile Farès et Rachid Koraïchi ainsi que l'essai Édouard Glissant et l'Algérie (pp. 45-52) de Mourad YELLES et enfin la section «Théâtre» (pp.53-61) dédiée à la pièce La récréation des clowns de Noureddine Aba.

2 Les trois contributions qui constituent la section littéraire nous paraissent particulièrement dignes d'intérêt. Elles partagent un sujet commun: victime d'une «réalité ogressale» (p.23) comme le souligne Mokhtari, l'Algérie postcoloniale, «dramatique et toujours présente» (p. 49), renvoie à la Palestine de Mahmoud Darwich, évoquée dans les gravures de Rachid Koraïchi. Emblème d'un «Tout Monde» (p. 49) à la dérive, l'Algérie est le théâtre du «Tragique» (p.51) de notre époque, l'exemple idéal qui montre, comme disait Glissant, le drame «de l'Homme en face des peuples, du destin personnel confronté à un destin collectif»(p.51). Caput mundi qui essaie de récupérer son «chant profond» (p. 52), l'Algérie contemporaine symbolise et résume les efforts de toute une humanité déçue par «l'Unique opaque» (p.50) et orientée vers la lumière d'une «Relation» (p. 50) in fieri. Ce numéro d' «Algérie Littérature/Action» offre à ses lecteurs des contributions qui privilégient l'incertitude d'une «pensée en construction» (p.50), selon les mots de Mourad Yelles, à la rassurante banalité des vieilles idées reçues. 